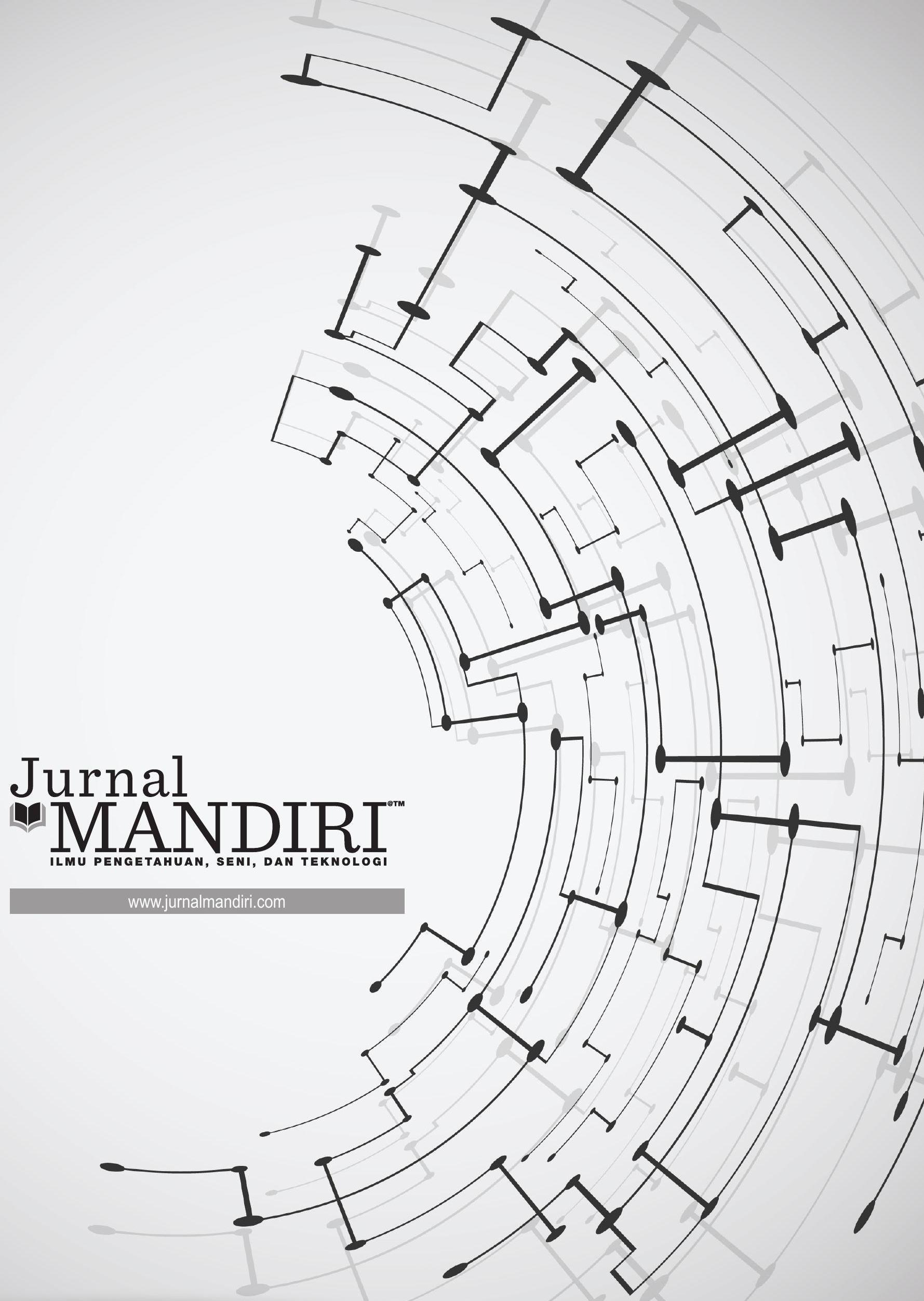


ISSN : 2580-3220, E-ISSN : 2580-4588

J. Mandiri., Vol. 3, No. 2, Desember 2019 (183 - 193)

(C)2018 Lembaga Kajian Demokrasi

dan Pemberdayaan Masyarakat (LKD-PM)

DOI : https://doi.org/10.33753/mandiri.v3i2.76

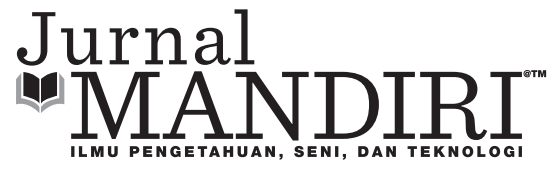

\title{
Analisis Penerapan Kebijakan Penghapusan Pajak Yang Seharusnya Terutang
}

\author{
Dinar Ambarita \\ Fakultas Ekonomi, Universitas Pamulang \\ happy.ambarita@gmail.com
}

\begin{abstract}
Abstrak
Kebijakan penghapusan pajakyang seharusnya terutang diterbitkan dengan tujuan mempercepatpertumbuhan ekonomi dan restrukturisasi melalui pengalihan harta, mendorong reformasi perpajakan, memperluas basis data perpajakan yang lebih valid dan meningkatkan penerimaan pajak. Penelitian dilakukan dengan metode kualitatif. Dari penelitian ini ditemukan bahwa dalam penerapannya kebijakan tersebut masih belum berhasil sesuai dengan tujuannya. Untuk itu perlu sosialisasi yang mantap, pengolahan basis data yang ketat guna untuk pengawasan dan melakukan penegakan hukum demi keadilan.
\end{abstract}

Kata Kunci : Pengampunan Pajak, Sosialisasi Kebijakan Perpajakan, Penerapan dan Pengawasan, Penegakan Hukum dan Keadilan

\begin{abstract}
The Policy of Elimination of Taxes That Should Be Payable published with purpose Accelerate economic growth and restructuring through the transfer of property, encouraging tax reform, expanding the tax database more valid and increasing tax revenue. The research was conducted by qualitative method. From this study found that in its application the policy still has not succeeded in accordance with its purpose. For that it needs a solid socialization, rigorous database processing for the supervision and law enforcement for justice.
\end{abstract}

Keywords : Tax Amnesty, Socialization of Tax Policy, Implementation And Supervision, Law Enforcement And Justice

\section{PENDAHULUAN}

Pertumbuhan ekonomi nasional dalam beberapa tahun terakhir cenderung mengalami perlambatan yang berdampak pada turunnya penerimaan pajak dan mengurangi ketersediaan likuiditas dalam negeri yang sangat diperlukan untuk meningkatkan pertumbuhan ekonomi Indonesia, sementara banyak Harta warga negara Indonesia yang ditempatkan di luar wilayah Indonesia yang seharusnya dapat dimanfaatkan untuk menambah likuiditas dalam negeri dan mendorong pertumbuhan ekonomi nasional.

Pengampunan pajak ini dilakukan dalam bentuk pelepasan hak negara untuk menagih pajak yang seharusnya terutang. Untuk itu sudah sewajarnya Wajib Pajak (WP) diwajibkan untuk membayar uang tebusan atas pengampunan pajak yang diperolehnya dalam rangka pelaksanaan undang-undang ini, penerimaan uang tebusan diperlakukan sebagai penerimaan pajak penghasilan.

Penerimaan pajak, yang meliputi pemasukan pajak serta bea dan cukai, merupakan tulang punggung anggaran negara. Dalam Anggaran Pendapatan dan Belanja Negara Perubahan 2015, penerimaan perpajakan ditargetkan dalam 
Anggaran Pendapatan dan Belanja Negara (APBN).

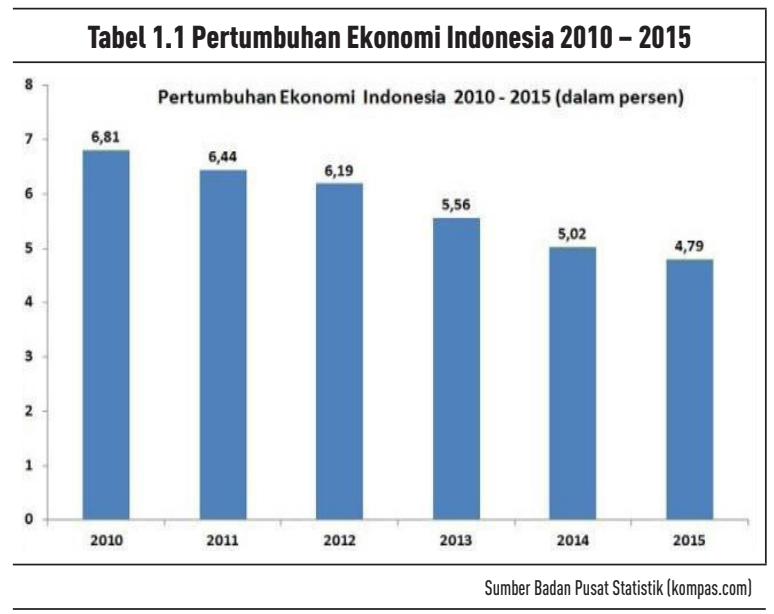

Jika kita melihat data pertumbuhan ekonomi nasional, pertumbuhan ekonomi Indonesia dalam beberapa tahun terakhir cenderung mengalami perlambatan sebesar Rp1.489,3 triliun atau hampir 80 persen dari total penerimaan Negara dan dapat dilihat pada realisai 5 (lima) tahun terakhir seperti berikut : tahun 2010: 97,3 persen target: Rp743 triliun realisasi: Rp723 triliun, tahun 2011 : 99,4 persen target : Rp879 triliun realisasi : Rp874 triliun, tahun 2012 : 96,4 persen target : Rp1.016 triliun realisasi : Rp981 triliun, tahun 2013 : 93,8 persen target : Rp1.148 triliun realisasi : Rp1.077 triliun dan tahun 2014: 91,7 persen target : Rp1.246 triliun realisasi : Rp1.143 triliun.

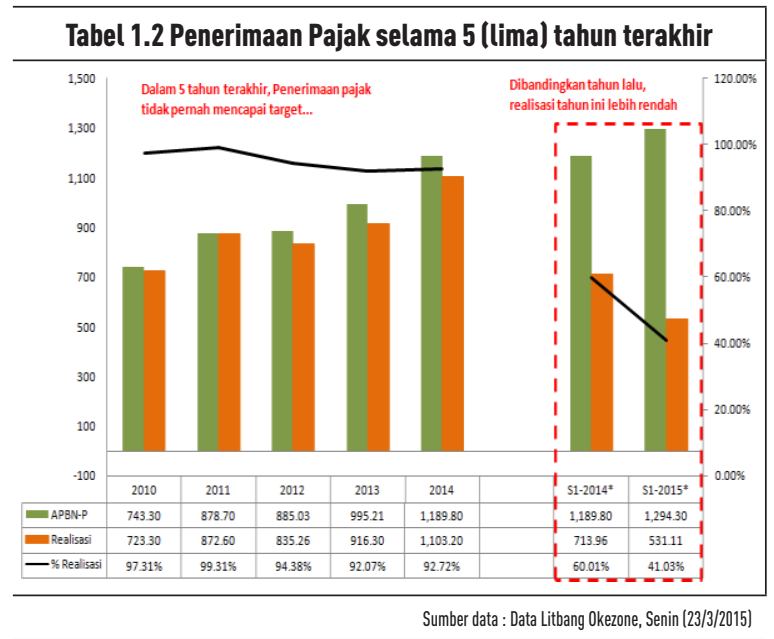

Di sisi lain, banyak harta warga negara Indonesia yang ditempatkan diluar wilayah negara Republik Indonesia, baik dalam bentuk likuid maupun nonlikuid. Yang seharusnya dapat di- manfaatkan untuk menambah likuiditas dalam negeri yang dapat mendorong pertumbuhan ekonomi nasional.

Untuk itu, perlu diterapkan langkah khusus dan terobosan kebijakan untuk mendorong pengalihan Harta ke dalam wilayah Indonesia sekaligus memberikan jaminan keamanan bagi warga negara Indonesia yang ingin mengalihkan dan mengungkapkan Harta yang dimilikinya dalam bentuk Pengampunan Pajak. Terobosan kebijakan berupa Pengampunan Pajak juga didorong oleh semakin kecilnya kemungkinan untuk menyembunyikan kekayaan di luar wilayah Indonesia karena semakin transparannya sektor keuangan global dan meningkatnya intensitas pertukaran informasi antarnegara.

Tujuan dari Pengampunan Pajak dalam jangka pendek adalah untuk meningkatkan penerimaan pajak pada tahun diterimanya Uang Tebusan yang berguna untuk membiayai berbagai program yang telah direncanakan.

Dalam jangka panjang, Negara akan mendapatkan penerimaan pajak dari tambahan aktivitas ekonomi yang berasal dari Harta yang telah dialihkan dan diinvestasikan di dalam wilayah Indonesia. Pengampunan Pajak diberikan kepada seluruh Pajak yang timbul atas pengungkapan harta yang diajukan Amnesti yaitu Pajak Penghasilan (PPh), Pajak Pertambahan Nilai (PPN), dan Pajak Penjualan atas Barang Mewah (PPnBM).

\section{METODE}

Banyak cara yang ditempuh dalam metode penelitian seperti yang penulis utarakan dalam Bab III ini, peneliti menyajikan metode atau prosedur penelitian yang akan diterapkan. Pembahasan berikutnya adalah Subbab penentuan informan, teknik pengumpulan data, rencana analisis data, uji keabsahan data, serta lokasi dan jadwal penelitian.

Penelitian pada hakekatnya merupakan suatu upaya untuk menemukan kebenaran. Usaha untuk mengejar kebenaran dilakukan oleh para filsuf, peneliti, maupun oleh para praktisi melalui model-model tertentu. Model tersebut biasanya 
dikenal dengan paradigma, menurut Bogdan dan Biklen (1982 : 32) adalah kumpulan longgar dari sejumlah asumsi yang dipegang bersama, konsep atau preposisi yang mengarahkan cara berpikir dan penelitian.

Paradigma merupakan pola atau model tentang bagaimana sesuatu distruktur (bagian dan hubungan) atau bagaimana bagian-bagian berfungsi (perilaku yang didalamnya ada konteks khusus atau dimensi waktu). Khun (1962) dalam "The Structure of Scintific Revolution" mendefinisikan "Paradigma Ilmiah" sebagai contoh yang diterima tentang praktik ilmiah sebenarnya, contoh-contoh termasuk hukum, teori, aplikasi, dan instrumenasi secara bersama-sama yang menyediakan model yang dirinya muncul tradisi yang koheren (timbal balik) dari penelitian ilmiah.

Penelitian yang pelaksanaannya didasarkan pada paradigma bersama, berkomitmen untuk menggunakan aturan dan standar praktik ilmiah yang sama. Selain paradigma ilmiah, dikenal juga paradigma alamiah atau paradigma naturalistik, menurut Guba dan Lincoln (1985: 37) mengemukakan dua paradigma utama, yakni paradigma positivisme dan paradigma naturalistik.

Di dalam penelitian ini, penulis memilih untuk menggunakan paradigma naturalistik yang sesuai dengan pendekatan kualitatifkarena penulis berpendapat, bahwa suatu pilihan kebijakan yang dipersepsi oleh masyarakat memilih banyak kemungkinan jawaban yang pada hakekatnya sesuai dengan keadaan sebenarnya atau natural yang berkembang dimasyarakat.

Pendekatan penelitian yang digunakan dalam studi ini adalah pendekatan kualitatif. Pendekatan ini didefinisikan sebagai tradisi tertentu dalam ilmu pengetahuan sosial yang secara fundamental bergantung pada pengamatan manusia dalam kawasannya sendiri, berhubungan dengan orangorang tersebut dalam bahasannya serta peristilahannya (Moleong : 1994).

Menurut Creswell (2003), pendekatan kualitatif adalah pendekatan untuk membangun pernyataan pengetahuan berdasarkan prespektifkontruktif (misalnya, makna-makna yang bersumberdaripengalaman individu, nilai-nilai sosial dan sejarah, dengan tujuan untuk membangun teori atau pola pengetahuan tertentu), atau berdasarkan perspektif partisipatori (misalnya: orientasi terhadap politik, isu, kolaborasi, atau perubahan), atau keduanya.

Menurut Neuman, membedakan penelitian menjadi pendekatan kuantitatif dan pendekatan kualitatif sebagaimana tercermin dalam judul buku Neuman tersebut: "..qualitative and quantitative approaches". Dalam penyusunan tesis ini penulis menggunakan pendekatan kualitatif karena mempertimbangkan fokus penelitian adalah penerapan kebijakan penghapusan pajak yang seharusnya terutang dilaksanakan dengan berhasil karena penulis ingin mengungkapkan apa saja entitas yang terkait dengan penerapan kebijakan penghapusan pajak yang seharusnya terutang sehingga akan meningkatkan kepatuhan Wajib pajak yang terkait dengan persepsi wawancara terhadap kebijakan tersebut.

Lebih jauh, Creswell menjelaskan bahwa di dalam penelitian kualitatif, Dimensi Pertama adalah pengetahuan dibangun melalui interpretasi (gambaran) terhadap multi perspektif yang beragam dari masukan segenap partisipan yang terlibat didalam penelitian, tidak hanya dari penelitiannya semata. Sumber datanya bermacam-macam, seperti catatan observasi, catatan wawancara pengalaman individu, dan sejarah. Dimensi kedua adalah dimensi tujuan penggunaan. Terdapat 2 (dua) dimensi dilihat dari tujuh penggunaan, yang pertama bersifat murni (basic, pure research) dan yang kedua bersifat terapan (applied). Memperhatikan hakekat tesis ini adalah kajian terhadap pengaruh suatu kebijakan, maka hasilnya diharapkan dapat menjadi pedoman perbaikan atau bahan perbandingan dalam suatu kebijakan perpajakan di Indonesia.

Hasil penelitian ini dapat digunakan oleh pemerintah (dalam hal ini Direktorat Jendral Pajak), Wajib Pajak, dan konsultan pajak maupun akademis. Dimensi ketiga adalah dimensi tujuan penjelasan. Kajian terhadap data penelitian lapangan akan disajikan secara redaksional serta menggambarkan entitas-entitas terkait yang membentuk penerapan kebijakan penghapusan 
pajak yang seharusnya terutang karena itu dimensi dalam penelitian ini ditinjau dari segi tujuan penjelasan bersifat deskriptip. Dimensi ke empat adalah dimensi waktu.

Neuman membedakan tiga dimensi penelitian yang terkait dengan waktu, yakni yang pertama, adalah cross-sectional, yang kedua, longitudinal yang terdiri dari panel, time series dan cohort analysis serta yang ketiga adalah case study atau studi kasus. Dimensi yang pertama dan kedua diterapkan untuk penelitian dengan pendekatan kuantitatif, sedangkan dimensi yang ketiga yakni studi kasus untuk pendekatan kualitatif. Karena pendekatan dalam tesis ini adalah pendekatan kualitatif, maka dari dimensi waktu, tesis ini termasuk dalam pemahaman studi kasus tersebut. Case study atau studi kasus, berarti melakukan kajian terhadap satu realitas sosial. Kajian dilakukan secara mendalam dari berbagai segi.

Sementara itu, Denzin dan Lincoln (2003: 36) mengelompokkan studi kasus, dan antara lain gronded theory dan phenomenology di bawah payung research strategy. Dalam tesis ini, penulis menerapkan studi kasus dalam arti studi mendalam yang dikaji dari berbagai aspek yang sekaligus berbagai strategi untuk memperoleh pendapat yang bersangkutan. Ciri utama dari suatu kasus adalah wawancara mendalam dalam menghimpun data "...many features in of a few cases over a duration time" (Neuman : 2003, 33) yakni menghimpun banyak ciri atau sifat tertentu dalam sudut kasus pada waktu tertentu.

Pada penelitian ini akan dihimpun sebanyak mungkin ciri atau sifat yang melekat pada persepsi penjawab kuesioner selama penelitian berlangsung, yakni antara bulan April 2017 sampai dengan Juli 2017. Dimensi kelima adalah dimensi pengamatan. Neuman menyajikan field research di sini adalah tidak berarti secara harafiah penelitian lapangan, tetapi lebih pada metode dan strategi memformulasikan ide atau topik. Dalam field research pada pendekatan kualitatif, peneliti memulai dengan ide yang longgar. Ide yang longgar tersebut dalam tesis ini adalah apakah masyarakat atau Wajib Pajak dalam mengikuti Pengampunan Pajak akan mempermudah memenuhi kewajibannya dibandingkan dengan sebe- lumnya.

Adapun jenis penelitian dalam studi ini adalah deskriptif, di mana data atau informasi yang diperoleh atau dikumpulkan tidak berbentuk angka, tetapi dalam bentuk kata, kalimat, pernyataan dan konsep. Penelitian ini lebih ke arah menggambarkan kondisi-kondisi yang terjadi serta mencari tahu faktor-faktor apa saja yang kira-kira turut ambil bagian dalam penerapan kebijakan penghapusan pajak yang seharusnya terutang. Hal tersebut diperoleh dari prespektif aparatur pajak, Wajib Pajak, dan Ahli Pajak.

Studi dilakukan terhadap informan yang berada di wilayah kerja Kantor Pusat Direktorat Jenderal Pajak dan pihak luar yaitu ahli pajak. Pemilihan pendekatan kualitatif dalam penelitian ini didasarkan pada pertimbangan untuk menggambarkan secara lebih memadai perspektif terhadap kebijakan perpajakan dari sisi konteks pelaku sosial yang ada dalam setting kebijakan perpajakan yakni aparatur dan masyarakat wajib pajak.

Informan adalah penjawab pertanyaan dalam wawancara mendalam, yakni individu yang diyakini mempunyai dan menguasai informan tentang topik penelitian. Menurut Guba dan Liocoln (1985: 199) menggariskan, bahwa dalam pendekatan kualitatif, sampling harus ditentukan sebelumnya untuk tujuan tertentu : purposive sampling, yakni mendapatkan informasi yang dibutuhkan dari individu yang tepat. Sampling di sini terkait dengan siapa yang akan memberi informasi, belum terkait dengan berapa jumlah informan yang akan memberikan Jumlah informan yang dibutuhkan tidak didasarkan pada hitungan statistik, tetapi tergantung pada kejenuhan data yang diperoleh sebagaimana dikatakan Guba dan Licoln (1985 : 202) : "Informational redundance, not a statistical confidence level". Berdasarkan hal ini, tingkat kejenuhan jawaban tercapai pada informan yang ke $B$.

Informan (info) yang terpilih berdasarkan purposive sampling diatas dapat disajikan sebagai berikut ;

a. Aparatur pajakyang bertugas di DJP menjabat sebagai Kasubag Dir.Peraturan Perpajakan II.

b. Praktisi Pajak sebanyak 3 (tiga) orang sebagai 
pegawai di Kantor Konsultan Pajak.

c. Wajib Pajak yang terdaftar di tempat yang berbeda sebanyak 5 (lima) orang akademis sebagai Dosen di Institute STIAMI.

Lincoln dan guba (1985) mengemukakan bahwa "Naturalistic sampling is, then, very different from conventional sampling. It is based on informational, not statistical, considerations. Its purpose is to maximize information, not to facilitate generational". Penentuan sampel dalam penelitian kualitatif (naturalistik) sangat berbeda dengan penentuan sampel dalam penelitian konvensional (kuantitatif). Penelitian sampel dalam kualitatif tidak didasarkan perhitungan statistik. Sampel yang dipilih berfungsi untuk mendapatkan informasi yang maksimum, bukan untuk digeneralisasikan.

Oleh karena itu, menurut Lincoln dan Cuba (1985), dalam penelitian natulistik spesifikasi sampel tidak dapat ditentukan sebelumnya. Ciriciri khusus sampel purposive yaitu :

1. Emergen sampling design (sementara).

2. Serial selection of sample unit (menggelinding seperti bola salju/snow ball).

3. Continous adjustmen or focusing of the sampel (disesuaikan dengan kebutuhan).

4. Selection to the point of redundancy (dipilih sampai jenuh).

Jadi, penentuan sampel dalam penelitian kualitatif dilakukan saat peneliti mulai memasuki lapangan dan selama penelitian berlangsung (Emergent sampling Design). Caranya yaitu, peneliti memilih data yang diperlukan; selanjutnya berdasarkan data atau informasi yang diperoleh dari sampel sebelumnya itu, peneliti dapat menetapkan sampel lainnya yang dipertimbangkan akan memberikan data lebih lengkap.

Praktik inilah yang disebut sebagai "serial selection of sample unit" (Lincoln dan Guba, 1985), atau dalam kata-kata bogdan dan Biklen (1982) dinamakan "Snowball sampling techniquw". Unit sampel yang dipilih makin lama makin terarah sejalan dengan makin terarah fokus penelitian. Proses ini dinamakan Bogdan dan Biklen (1982) sebagai "continous adjustment of the sample".

Dalam proses penentuan sampel seperti dijelaskan diatas, berapa besar sampel tidak dapat ditentukan sebelumnya. Seperti telah dikutip di atas, dalam sampel purposive besar sampel ditentukan oleh pertimbangan informasi. Seperti ditegaskan oleh Lincoln dan Guba (1985) bahwa "if the purpose is to maximize information, then sampling is terminated when no new informationis forth-coming from newly sampled units : thus redundancy is the primery criterion".

Pengumpulan data pada dasarnya merupakan proses penelitian untuk mendapatkan data atau informasi yang menjelaskan suatu permasalahan yang hendak di teliti. Teknik pengumpulan data dapat dikelompokkan menjadi dua kategori: kuantitatif, lewat pengumpulan data dalam bentuk angka, dan kualitatif, melalui pengumpulan data dalam bentuk kata-kata atau gambar (Neuman, 2003:35). Studi ini sendiri menggunakan pengumpulan data kualitatif. Data pada studi ini terbagi atas dua bagian, yaitu data primer dan data skunder.

Menurut Ibrahim (2015:68) Data primer adalah segala informasi, fakta, dan realitas yang terkait atau relevan dengan penelitian, dimana kaitan atau relevansinya sangat jelas, bahkan secara langsung. Disebut sebagai data utama (primer), karena data tersebut menjadi penentu utama berhasil atau tidaknya penelitian. Artinya, hanya dengan didapatkannya data tersebut sebuah penelitian dapat dikatakan berhasil dikerjakan. Dari data itulah pertanyaan utama penelitian dapat dijawab. Dari data itu pula, penelitian tersebut dapat dikembangkan menjadi lebih detil, mendalam dan rinci.

Data yang memiliki karakteristik inilah yang disebut dengan data utama (primer). Bungin (2013 : 128) mendefinisikan data primer sebagai data yang diambil dari sumber primer atau sumber pertama dilapangan. Data Primer lebih banyak bersumber dari proses tanya jawab atau wawancara mendalam dengan informan. Data Primer diperoleh dengan teknik pengumpulan data kualitatif. Berikut adalah uraian tentang tehnik pengumpulan data primer yang akan digunakan dalam pengamatan ini.

Wawancara merupakan percakapan yang diarahkan pada suatu masalah tertentu. Ini merupakan proses tanya jawab di mana dua orang 
atau lebih berhadapan secara fisik (Kartini dan Kartono, 1980:139). Dalam konteks penelitian kualitatif, Lincoln dan Guba menyatakan bahwa maksud mengadakan wawancara adalah untuk mengontruksi mengenai kejadian, kegiatan, organisasi, perasaan, motivasi, tuntutan, kepedulian orang-orang di dalam suatu kelompok (Moleong: 1994).

Hasil wawancara merupakan perolehan data penelitian lapangan (field research) yang merupakan jenis kualitatif. Melalui penelitian lapangan, peneliti berinteraksi langsung dilapangan selama kurun waktu tertentu. Selanjutnya peneliti memilih kelompok sosial (social group) atau tempat (site) untuk melakukan studi. Peneliti dapat mengenai secara lebih personal dan memungkinkan untuk wawancara pada individu-individu pada kelompok sosial atau tempat tersebut (Neuman, 2003:390).

Menurut Ibrahim (2015:83) pengamatan dalam penelitian ini menggunakan pengamatan berperan serta (participant observation). Observasi Partisipatif (paticipant observation) adalah teknik pengumpulan data yang dilakukan dengan cara berpartisipasi atau terlibat langsung dalam situasi alamiah objek yang diteliti.

Adapun tujuan melakukan pengamatan dalam penelitian ini, mengacu pada pernyataan yang dikemukakan oleh Guba dan Lincoln (Moleong : 1994), yaitu :

1) Teknik pengamatan didasarkan atas pengalaman secara langsung karena pengamatan langsung merupakan alat yang ampuh untuk mengetes suatu kebenaran.

2) Teknik pengamatan juga memungkinkan melihat dan mengamati sendiri, kemudian mencatat perilaku dan kejadian sebagaimana yang terjadi pada keadaan sebenarnya.

3) Pengamatan memungkinkan peneliti mencatat peristiwa dalam situasi yang berkaitan dengan pengetahuan proporsional maupun pengetahuan yang langsung diperoleh dari data.

4) Sering terjadi ada keraguan peneliti oleh karena data yang didapat kemungkinan bisa dikarenakan kurang dapat mengingat peristiwa atau hasil wawancara, adanya jarak antara peneliti dengan yang diwawancarai, ataupun karena reaksi peneliti yang emosional pada suatu saat. Maka teknik pengamatan merupakan jalan yang terbaik untuk mengecek kepercayaan data tersebut.

5) Teknik pengamatan memungkinkan peneliti mampu memahami situasi- situasi yang rumit dan perilaku yang kompleks, dalam kasus-kasus tertentu dimana teknik komunikasi lainnya tidak mungkin dilakukan, pengamatan dapat menjadi alat yang bermanfaat.

Data lapangan hasil pengamatan adalah pengalaman-pengalaman atau ingatan peneliti, dan yang direkam dan ditulis dalam catatan lapangan (field notes), sehingga menjadi analisa yang sistematis (Neuman, 2003:383).

Penelitian ini akan mempergunakan teknik participant observer (peserta sebagai pengamat), yakni mencoba membentuk serangkaian hubungan dengan subjek, sehingga mereka berfungsi sebagai informan. Teknik untuk membangun hubungan dengan subjek ini dapat dimungkinkan karena informan adalah wajib pajak yang terdaftar di wilayah kerja Kantor Pusat Direktorat Jenderal Pajak. Participant observer juga digunakan untuk membangun hubungan dengan aparatur pajak dalam rangka perolehan data-data. Demikian juga halnya dengan ahli perpajakan, yang adalah ahli pajak dan cukup dikenal dekat sebelumnya.

Data sekunder yang digunakan untuk melengkapi penelitian ini adalah data jumlah Wajib Pajak yang menyerahkan Surat Pernyataan Harta atau wajib pajak yang mengikuti program pengampunan pajak. Adapun teknik yang digunakan dalam penelitian data sekunder adalah existing statistics. Dalam Existing Statistich research ini, penelitian mencari sumber informasi yang telah dikumpulkan sebelumnya, seringkali dalam bentuk laporan pemerintah atau hasil survei (Neuman, 2003:317).

Existing statistich research dapat digunakan untuk tujuan eksploratif, deskriptif maupun eksplanatif, tetapi lebih sering digunakan untuk riset deskriptif (Neuman, 2003:318). Hal ini sesuai dengan sifat penelitian dalam studi ini, yakni deskriptif. Dalam Existing statistich research, 
peneliti menyusun kembali atau menggabungkan informasi dalam cara-cara baru untuk menjawab pertanyaan penelitian (Neuman, 2003:318). Dalam konteks penelitian ini, Existing statistich research digunakan untuk menjawab pertanyaan penelitian kedua, yakni entitas yang membentuk Penerapan Kebijakan Penghapusan Pajak yang seharusnya terutang dapat berhasil.

Penelitian data sekunder dalam penelitian ini bersumber dari data yang diperoleh dari Kantor Pusat Direktorat Jenderal Pajak berupa data jumlah repatriasi dan deklarasi di Kantor Pusat Direktorat Jenderal Pajak untuk periode 1 Juli 2016 sampai dengan 31 Maret 2017. Data sekunder yang diperoleh bersifat mendukung (supporting) penelitian yang menggunakan pendekatan kualitatif ini.

Metode analisis data yang digunakan peneliti adalah inductive data analisys (Lincoln \& Guba, 1985) yakni metode analisis umum dilakukan para peneliti yang didasarkan pada hasil penelitian lapangan seperti wawancara. Proses selanjutnya untuk mengungkapkan informasi yang tersembunyi (tacit information), peneliti menerapkan unitizing dan categorizing. Unitizing adalah proses coding, yakni data mentah secara sistematis ditransformasikan dan dihimpun kepada unit-unit yang cenderung memiliki diskripsi yang tepat dari inti sifat-sifat yang relevan. Categorizing adalah proses data yang sudah diunitkan/disatukan sebelumnya diorganisasikan dalam beberapa kategori sedemikian rupa sehingga tersediannya kesimpulan deskripsi atau informasi tentang konteks atau kedudukan dari mana unit-unit itu berasal.

Rencana uji keabsahan data merujuk kepada Lincoln dan Guba (985:301-331), terdapat empat kriteria untuk menentukan apakah data yang data yang diperoleh peneliti dari lapangan sudah mencapai tingkat keabsahan (trustwoethiness criteria). Kriteria pertama adalah credibility, kepercayaan atau dapat dipercaya yang disandingkan dengan pendekatan kualitatif yang "iterated until redudancy" berulang kali sampai tercapai kejenuhan (Lincoln \& Guba :1985,301-331), maka peneliti dalam proses berkali-kali ke lapangan itu dianggap telah cukup lama mengamati dan mengolah data yang bersangkutan, mempelajari budaya, menguji informasi yang keliru, meminimalisasi distorsi dan terutama membangun kepercayaan. Hal ini dapat dilakukan dengan cara peneliti menggunakan sumber yang ada.

Selanjutnya data dapat dikatakan telah mendapat kepercayaan apabila memenuhi kriteria persisten observation, observasi yang gigih dalam arti peneliti secara konsisen dan terus melakukan pengamatan. Tujuan observasi yang gigih adalah mengungkapkan sifat dan unsur yang sangat relevan dari fokus penelitian serta menyajikan informasi yang terinci. Jika pada keterlibatan yang lama menghasilkan atau tercapainya lingkup data hasil penelitian, maka pada observasi yang gigih tercapai kedalaman data hasil penelitian.

Akhirnya data dapat dikatakan mencapai kepercayaan atau dapat dipercaya apabila data hasil penelitian itu telah diuji dengan mode-mode (modes) verbatim, dimana dalam melakukan analisis data mengharuskan peneliti diam dengan penelitian data. Analisis data dilakukan untuk mengetahui keunikan pengalaman hidup masingmasing peserta sementara, memungkinkan pemahaman tentang fenomena yang diteliti. Hal ini dimulai dengan mendengarkan deskripsi peserta dan diikuti dengan membaca ulang transkripsi verbatim (Henning: 127-128).

Kriteria kedua dari keabsahan data adalah tranferability, dapat dialihkan yang disandingkan. Kriteria ketiga dari keabsahan data adalah dependability, yang dapat diandalkan. Kriteria keempat adalah confirmability, dapat ditegaskan.

Setelah menjabarkan hal-hal yang melatar belakangi penelitian, teori-teori yang telah mengkukuhkan penelitian, maupun metode penelitian yang digunakan, maka bab ini akan dipaparkan mengenai lokasi dan jadwal penelitian. Untuk lokasi penelitian dilakukan di Kantor Pusat Direktorat Jenderal Pajak, Jl. Gatot Subroto Kav.40-42, Kota Jakarta Selatan, Daerah Khusus Ibukota Jakarta.

\section{HASIL dan PEMBAHASAN \\ Hasil}

Temuan penelitian yang penulis lakukan di- 
hasilkan baik melalui analisis data, wawancara maupun observasi secara langsung. Peneliti melakukan analisis data terhadap penerapan kebijakan Penghapusan Pajak Yang Seharusnya Terutang pada Kantor Pusat Direktorat Jenderal Pajak. Diketahui bahwa kebijakan demi kebijakan diterbitkan guna untuk meningkatkan penerimaan negara. Peneliti merangkum analisa data nya sebagai berikut :

- Dari Rp1.000 triliun target dana repatriasi, hanya Rp147 triliun yang terealisasi.

- Penerimaan Pajak masih jauh dari target.

- Jumlah Wajib Pajak yang terdaftar mengalami peningkatan.

- Penerimaan Pajak di semester pertama tahun 2017 meningkat dibanding penerimaan pajak semester pertama tahun 2016.

Penulis melakukan wawancara terhadap 10 (sepuluh) orang informan yang berlatar-belakang dan berprofesi dibidang perpajakan yaitu wajib pajak, praktisi, akademis dan aparatur pajak. Sebagaimana yang telah dijelaskan sebelumnya bahwa wawancara ini dilakukan untuk memperoleh pendapat atas pertanyaan dari informan sampai dengan tahap jenuh.

Penulis membuat pedoman wawancara tertulis dengan pertanyaan yang sama terhadap semua informan. Seluruh hasil wawancara yang telah diterima oleh peneliti dilakukan kompilasi atas jawaban dari 10 (sepuluh) informan dalam kompilasi hasil wawancara dengan penemuan sebagai berikut :

1. Kebijakan penghapusan pajak yang seharusnya terutang tidak adil.

2. Kebijakan penghapusan pajak yangs seharusnya terutang jika dilihat dari sisi UUD 45 nya adalah tidak adil.

3. Kebijakan penghapusan pajak yang seharusnya terutang memberikan pembebasan Pajak.

4. Penerapan kebijakan penghapusan pajak yang seharusnya terutang mempersulit para aparat pajak.

5. Penerapan kebijakan penghapusan pajak yang seharusnya terutang memberikan kesulitan bagi wajib pajak.

6. Penerapan kebijakan penghapusan pajak yang seharusnya terutang belum berhasil membawa harta warga indonesia yang berada di luar negeri masuk ke dalam NKRI.

7. Tujuan diterapkannya kebijakan penghapusan pajak yang seharusnya terutang belum berhasil menjalankan fungsinya sebagai budgeter.

8. Penerapan kebijakan penghapusan pajak yang seharusnya terutang menjerat para wajib pajak.

Dapat disimpulkan bahwa penerapan kebijakan penghapusan pajak yang seharusnya terutang dapat berhasil apabila kebijakan tersebut dibarengi dengan implementasi yang kuat seperti sosialisasi dijalankan dengan tidak terburu-buru melainkan dengan rapih dan terstruktur di mana penjelasan demi penjelasan diberikan sedalam dan sejelas mungkin supaya wajib pajak tidak mendapat informasi yang sepihak atau sepenggal dan wajib pajak tidak ragu-ragu ataupun takut dalam mengikuti suatu kebijakan yang diterbitkan, pemerintah dapat melakukan simulasi atas apa yang hendak terjadi pada saat suatu kebijakan diterapkan, dengan sosialisasi yang tidak terburu-buru pun dapat menjelaskan letak keadilan kebijakan tersebut dan tidak merasa dijerat, dengan sosialisasi yang baik dan jelas juga akan mempermudah baik aparat pajak maupun wajib pajak itu sendiri untuk ikut serta dalam menjalankan kebijakan dan sosialisasi yang baik pun dapat meraih kepercayaan dari wajib pajak sehingga repatriasi dapat tercapai.

Penulis juga melakukan observasi atau menggali informasi secara langsung dari para pelaku pajak yang mana dalam kenyataannya implementasi kebijakan penghapusan pajak yang seharusnya terutang tidak berjalan seperti yang diharapkan. Banyak wajib pajak yang peneliti temukan dilapangan dengan kebingungan dalam mengisi surat pernyataan, dalam melampirkan daftar hartanya, menghitung uang tebusan, penggunaan formulir harta dan masih banyak wajib pajak yang yang belum paham betul dengan penyajian Tax Amnesty dan cara membayar uang tebusannya. 


\section{Pembahasan}

Sebelumnya penulis telah menyebutkan dasar hukum tentang Penghapusan Pajak Yang Seharusnya Terutang yaitu Undang-undang No.11 tahun 2016 pasal 2 yang memiliki tujuan umum yaitu :

a. Mempercepat pertumbuhan dan restrukturisasi ekonomi melalui pengalihan harta (repatriasi), yang antara lain akan berdampak terhadap pengingkatan likuiditas domestik, perbaikan nilai tukar rupiah, penurunan suku bunga, dan peningkatan investasi. Namun dari analisis data yang diperoleh penulis, target repatriasi hanya tercapai sebesar 15\% yakni 147 trillun dari 1.000 triliun dan dapat disimpulkan bahwa tax amnesty tidak berhasil sesuai dengan hasil data sekunder pada tabel 4.1 dan data primer pada tabel 4.9.

b. Mendorong reformasi perpajakan menuju sistem perpajakan yang lebih berkeadilan serta perluasan basis data perpajakan yang lebih valid, komprehensif, dan terintegrasi. Dalam analisis data sebelumnya, penulis menemukan bahwa kebijakan penghapusan pajak yang seharusnya terutang tidak adil menurut umum dan tidak adil menurut UUD 45 sesuai dengan data primer pada tabel 4.4 dan tabel 4.5 dan penulis juga menemukan target Wajib Pajak peserta tax amnesty adalah 2.000 .000 wajib pajak namun terealisasi hanya $48 \%$ dengan jumlah 965.983 wajib pajak sesuai data sekunder pada tabel 4.1 dimana angka tersebut masih sangat jauh dari target dan data base wajib pajak masih belum tercapai dengan maksimal yang mana hingga program tax amnesty selesai jumlah wajib pajak terdaftar hanya mengalami kenaikan 19,93\% yaitu sebanyak 5.987 .869 wajib pajak seperti yang ditampilkan pada data sekunder tabel 4.2 .

c. Meningkatkan penerimaan pajak, yang antara lain akan digunakan untuk pembiayaan pembangunan. Pada kenyataannya, peningkatan penerimaan pajak terjadi namun hanya $11 \%$ namun wajib pajak yang mengikuti program tax amnesty belum menunjukkan niat baiknya seperti yang disebut data sekunder pada tabel 4.3 dengan kenaikan penerimaan pajak hanya $10,37 \%$ pada semester pertama tahun 2017 dan terbukti juga bahwa hal ini hanya membebaskan para wajib pajak kalangan atas seperti hasil penelitian pada data primer tabel 4.6 dan tabel 4.10 .

Dari analisis data sekunder dan hasil wawancara mendalam terhadap para informan penulis membuat kesimpulan bahwa entitas yang saling terkait dengan penerapan kebijakan penghapusan pajak yang seharusnya terutang pada Kantor $\mathrm{Pu}$ sat Direktorat Jenderal Pajak yang semula teridiri dari :

1. Fenomena

2. Kebijakan Perpajakan

3. Sosialisasi

4. Implementasi \& Pengawasan

5. Penghapusan Pajak Yang Seharusnya Terutang

6. Evaluasi

7. Penegakan Hukum

8. Kepatuhan \& Integritas Wajib Pajak mengalami penambahan entitas yaitu :
a. Penegakan Keadilan
b. Basis Data
c. Pemeriksaan Pajak

\section{SIMPULAN}

Upaya pemerintah dalam mensukseskan penerapan kebijakan penghapusan atas pajak yang seharusnya terutang adalah menurunkan tingkat suku bunga bank dengan melakukan berbagai tindakan efisiensi dengan profesionalisme pengelolaan dan sumber daya manusia bank-bank negara perlu ditingkatkan, jenis produknya diperluas, dan mutu pelayanannya ditingkatkan. Memperkokoh sistem perpajakan dengan meningkatkan kualitas dari kebijakan yang diterbitkan dan menggali kembali potensi-potensi pajak yang ada melalui sosialisasi yang tepat dan memaksimalkan pengolahan data base wajib pajak yang sudah terjaring. Tindak tegas para penggelap pajak jika masih mengulangi tindakan menggelapkan pajak termasuk para aparat pajak yang ikut serta ambil bagian. Dan, hal upaya ini masih belum terbukti berhasil selama tahun 2017 
berjalan.

Penerapan kebijakan penghapusan atas pajak yang seharusnya terutang seharusnya mendorong reformasi perpajakan menuju sistem perpajakan supaya memiliki basis data perpajakan yang lebih valid, komprehensif, dan terintegrasi. kenyataannya target Wajib Pajak peserta Tax Amnesty adalah 2.000.000 wajib pajak namun terealisasi hanya 48\% dengan jumlah 965.983 wajib pajak di mana angka tersebut masih sangat jauh dari target dan data base wajib pajak masih belum tercapai dengan maksimal yang mana hingga program Pengampunan Pajak selesai jumlah wajib pajak terdaftar hanya mengalami kenaikan 19,93\% yaitu sebanyak 5.987.869 wajib pajak. Demikian juga fungsinya sebagai budgetter dalam meningkatkan penerimaan pajak, yang antara lain akan digunakan untuk pembiayaan pembangunan. Pada kenyataannya, peningkatan penerimaan pajak terjadi hanya $11 \%$ namun wajib pajak yang mengikuti program Tax Amnesty belum menunjukkan niat baiknya dengan kenaikan penerimaan pajak hanya $10,37 \%$ pada semester pertama tahun 2017 dibandingkan dengan semester pertama tahun 2016 yang artinya masih sangat minim.

Mempercepat pertumbuhan dan restrukturisasi ekonomi melalui pengalihan harta (repatriasi), yang antara lain akan berdampak terhadap pengingkatan likuiditas domestik, perbaikan nilai tukar rupiah, penurunan suku bunga, dan peningkatan investasi. Namun dari analisis data yang diperoleh penulis, target repatriasi hanya tercapai sebesar 15\% yakni 147 triliun dari 1.000 triliun. Hal ini dapat terjadi karena kurangnya sosialisasi dan seringnya aturan implementasi yang berubahubah yang kelihatannya pemerintah kurang percaya diri dimata para wajib pajak sehingga para wajib pajak pun menjadi merasa ragu untuk itu pemerintah harus mengambil sikap yang nyata baik dari segi hukum maupun keadilan.

\section{DAFTAR PUSTAKA}

Admosudirjo. (2005). Pengawasan Pada Sektor Bisnis. Batam

Astin, A.W. (1993). Assessment for Excellence. New York: American Counsil on Education,
Oryc Press

Browne dan Wildavsky dalam Nurdin dan Usman. (2003). Guru Profesional dan Implementasi Kurikulum. Jakarta: Ciputat Press

Carla Mechese, Universitas del Piemonte Orientale "Amedeo Avogadro", Alessandria, Italya. (2014). Tax Amnesty (International Programme in Institutions, Economic and Law Paper in Comparative Analysis of Institutions Economic and Law No.17)

Cleaves dalam Wahab. (2008). A Process Of Moving Toward A Policy Objective By Means Of Administrative And Political Step.

Danny Darussalam. (2016, June 17). Tax Center/ DDTC, Bawono Kristiaji, Tax Amnesty: Pemutihan Pajak dan Skandal Keuangan Terbesar?, https://nasional.kontan.co.id/news/ekonomada-empat-dampak-negatif-tax-amnesty.

Djajendra. (2012, June, 29). Berintegritas, www. djajendra- motivator.com.

Dr.Josephine. A.A. Agbonika Ph.D, LL.M, B.L, LL.B, JP, LSM. (2015). Senior Lecturer Kogi State University; also, commisioneer, Tax Appeal Tribunal, South East Zone, Enugu, Global Journal of Politics and Law Research Vol.3, No.3, Tax Amnesty for Delinquent Taxpayers: A Cliche in Nigeria. 105-120.

Erni Trisnawati, Sule dan Saefulah (2005:12), Pengantar Manajemen. Jakarta: Prenada Media Jakarta.

Fakhrani N. Syafrida. (2015). http:// journal. bakrie. ac.id/ indek.php/ jurnal__ ilmiah_ ub/article/view/1292 Vo.3, No.03Ssyafrida, Analisis Penerapan Tax Amnesty di Indonesia dalam Rangka Meningkatkan Penerimaan Negara pada Sektor Perpajakan.

Friedrich dalam Wahab. (2008). Definisi Implementasi Dan Teori Implementasi Oleh Para Ahli Di Dalam Sebuah Kebijakan, https:// www.materibelajar.id/2015/12/definisiimplementasi-dan-teori.html.

George R. Tery. (2006). Prinsip-Prinsip Manajemen. Jakarta: Penerbit Bumi Aksara.

Griffin \& Nix. (1991). Educational Assessment and Reporting. Sydney: Harcout Bracc Javanovich, Publisher.

James Alm+, Jorge Martinez- Vazquez, and Sally 
Wallance. (2009, September). Department of Economics, Andrew Young School of Policy Studies, Georgia State University, Atlanta, Georgia 30302-3992, USA, Do Tax Amnesties Work? The Revenues Effects of Tax Amnesties During the Transition in The Russian Federation - Economic Analysis \& Policy, Vol.39 No.2.

Kertonegoro. (1998). Perilaku di tempat kerja, Individu dan Kelompok. Jakarta: Yayasan Tenaga Kerja Indonesia.

KMK No.544 / KMK . 04 / 2000, Kriteria Wajib Pajak yang dapat diberikan Pengembalian Pendahuluan Kelebihan Pembayaran Pajak.

Made Wisnu Prawirasuta dan Putu Ery Setiawan. (2016, Agustus). Integritas sebagai pemoderasi pengaruh sanksi pajak dan kesadaran pada kepatuhan Wajib Pajak Pribadi, ISSN: 2302-8556, E-jurnal Akuntasi Universitas Udayana, Vol.16.2, 1661-1686.

Maringan. (2004). Dasar-Dasar Administrasi dan Manajemen. Jakarta: Ghalia Indonesia.

Maxmanian dan Sebastiar dalam Wahab. (2008). Analisis Kebijaksanaan Dari Formulasi ke Implementasi Kebijaksanaan Negara, Edisi Kedua. Jakarta: PT. Bumi Aksara.

PMK No.118/PMK.03/2016, Pelaksanaan Undang-Undang No.11 Tahun 2016 tentang Pengampunan Pajak.

PMK No.119/PMK.09/2016, Tata cara Pengalihan Harta Wajib Pajak ke dalam Wilayah Negara Kesatuan Republik Indonesia dan Penempatan pada Instrumen Investasi di Pasar Keuangan dalam Rangka Pengampunan Pajak.

Robbin dalam Sugandha (1999). Perilaku Organisasi, Konsep Kontroversi dan Aplikasi. Ahli Bahasa: Hadayana Pujaatmaka, Edisi Keenam. Jakarta: PT. Bhuana Ilmu Populer.

Rochmat Soemitro. (1988). Nazegeling.

Safri Nurmanto dalam Siti Kurnia Rahayu (2010), Kepatuhan Wajib Pajak. Malang: Empat Dua Media.

SE-30/PJ/2016, Petunjuk Pelaksanaan Pengampunan Pajak.

Siagian. (1990). Administrasi Pembangunan. Jakarta: Gunung Agung.

Stark, J.S. \& Thomas, A. (1994). Assesment and
Program Evaluation. Needham Heights: Simon \& Schuster Custom Pubisihing.

Stewart. (2015). Tax is Important Part of State Revenue and Taxation is an Important Issue.

Undang-Undang No.28 Tahun 2007, Ketentuan Umum Tata Cara Perpajakan.

Undang-Undang No.11 Tahun 2016, Pengampunan Pajak.

Yu-kun Wang. (2015, February 10). Departement of Business Administration, National Taipei University of Busines, No. 321,Sec.1, Jinan Rd., Zhongzheng District, Taipey City 100, Taiwan and Wen-Jen Hsieh, Department of Economics, National Cheng Kung University, No.1 University Road, Tainan City, 10101, Taiwan, Is Tax Amnesty Good for The Tax Evader? (Britihs Journal of Economics, Management \& Trade, ISSN : 2278-098X, Vol.:6, Issue.: 4 Received 21st November 2014, Accepted 28th January 2015. 